\title{
Burkholderia heleia sp. nov., a nitrogen-fixing bacterium isolated from an aquatic plant, Eleocharis dulcis, that grows in highly acidic swamps in actual acid sulfate soil areas of Vietnam
}

Correspondence

Michio Sunairi

sunairimichio@nihon-u.ac.jp

\author{
Tomoko Aizawa, ${ }^{1}$ Nguyen Bao Ve, ${ }^{2}$ Mutsuyasu Nakajima ${ }^{1,3}$ \\ and Michio Sunairi ${ }^{1}$
}
${ }^{1}$ Department of Applied Biological Sciences, College of Bioresource Sciences, Nihon University, 1866 Kameino, Fujisawa, Kanagawa 252-8510, Japan
${ }^{2}$ Department of Crop Science, College of Agriculture, Can Tho University, 3/2 Street, Can Tho, Vietnam
${ }^{3}$ Environmental Program, Nihon University Advanced Research Institute for the Sciences and Humanities, 12-5 Goban-cho Chiyoda, Tokyo 102-8251, Japan

\begin{abstract}
Nitrogen-fixing bacteria, strains SA41 ${ }^{\top}$, SA42 and SA53, were isolated from an aquatic plant, Eleocharis dulcis, that grows in highly acidic swamps $(\mathrm{pH} 2-4)$ in actual acid sulfate soil areas of Vietnam. The isolates were Gram-negative, aerobic, non-spore-forming, rod-shaped bacteria, having a cell width of $0.6-0.7 \mu \mathrm{m}$ and a length of 1.5-1.7 $\mu \mathrm{m}$. They showed good growth between $\mathrm{pH} 3.0$ and 7.0, and between 17 and $37^{\circ} \mathrm{C}$. The organisms contained ubiquinone Q- 8 as the predominant isoprenoid quinone, and $\mathrm{C}_{16: 0}, \mathrm{C}_{17: 0}$ cyclo, $\mathrm{C}_{18: 1} \omega 7 \mathrm{c}$ and summed feature $3\left(\mathrm{C}_{16: 1} \omega 7 \mathrm{c}\right.$ and/or iso- $\left.\mathrm{C}_{15: 0} 2-\mathrm{OH}\right)$ as major fatty acids. Their fatty acid profiles are similar to those reported for other Burkholderia species. The DNA G+C content of these strains was $64 \mathrm{~mol} \%$. On the basis of 16S rRNA gene sequence similarity, these strains were shown to belong to the genus Burkholderia. Although their calculated 16S rRNA gene sequence similarity values to Burkholderia silvatlantica, Burkholderia mimosarum, Burkholderia ferrariae and Burkholderia tropica were 98.5, 98.2, 98.0 and 97.0\%, respectively, the isolates formed a distinct group in phylogenetic trees, and the DNA-DNA relatedness values of strain SA $41^{\top}$ to these species were 39, 41, 39 and $33 \%$, respectively. The results of physiological and biochemical tests, including whole-cell protein pattern analysis, allowed phenotypic differentiation of these strains from the published Burkholderia species. Therefore, strains SA41 ${ }^{\top}, \mathrm{SA} 42$ and SA53 represent a novel species for which the name Burkholderia heleia sp. nov. is proposed. The type strain is SA $41^{\top}$ (=NBRC $101817^{\top}=$ VTCC-D6- $\left.7^{\top}\right)$.
\end{abstract}

Yabuuchi et al. first described the genus Burkholderia in 1992 by transferring seven species from Pseudomonas, with Burkholderia cepacia as the type species (Yabuuchi et al., 1992). Although only one $\mathrm{N}_{2}$-fixing species, Burkholderia vietnamiensis (Gillis et al., 1995), was reported in the genus until recently, a number of $\mathrm{N}_{2}$-fixers in Burkholderia have since been isolated from plants (maize, mimosas, sugar cane, teosinte) and soils, and subsequently classified as

Abbreviation: AASS, actual acid sulfate soil(s).

The GenBank/EMBL/DDBJ accession numbers for the 16S rRNA gene sequences of strains $\mathrm{SA} 41^{\top}, \mathrm{SA} 42$ and SA53 are AB495123, AB495124 and AB495125, respectively.

An extended phylogenetic tree, SDS-PAGE profiles of whole-cell extracts, and fatty acid compositions of the novel strains and related species are available as supplementary material in IJSEM Online. novel Burkholderia species, including Burkholderia mimosarum (Chen et al., 2006), Burkholderia nodosa (Chen et al., 2007), Burkholderia silvatlantica (Perin et al., 2006), Burkholderia tropica (Reis et al., 2004), Burkholderia unamae (Caballero-Mellado et al., 2004) and Burkholderia xenovorans (Goris et al., 2004). During the course of a study to develop bioremediation measures for actual acid sulfate soils (AASS; Sasaki et al., 2008), we isolated a number of bacteria associated with plants growing in highly acidic aquatic environments ( $\mathrm{pH} 2-4)$ of AASS in south-east Asia and found and reported a novel bacterial species, Curtobacterium ammoniigenes, among them (Aizawa et al., 2007). In the present study we characterized $\mathrm{N}_{2}$-fixing bacteria SA41 ${ }^{\mathrm{T}}$, SA42 and SA53, isolated from an aquatic plant, Eleocharis dulcis, that grows in highly acidic swamps ( $\mathrm{pH} \mathrm{2-4)}$ in AASS areas in Vietnam. By using a 
polyphasic approach, including 16S rRNA gene analysis, DNA-DNA hybridization, whole-cell protein analysis, fatty acid methyl ester analysis, and phenotypic and biochemical characterization, the strains were shown to be affiliated with the genus Burkholderia. The data obtained also suggest that the isolates represent a novel species of the genus Burkholderia.

A number of bacteria were isolated from plants of $E$. dulcis by using one-tenth-strength tryptic soy (1/10 TS) agar plates [3.0 g tryptic soy broth $\mathrm{l}^{-1}$ (Difco) solidified with $15.0 \mathrm{~g}_{\text {agar } \mathrm{l}^{-1}}$ (Difco); pH 4.0]. For preparation of acidic plates, double-strength medium and $3 \%$ agar solution were autoclaved separately and mixed after autoclaving to prevent hydrolysis of the agar. Among these isolates, $\mathrm{N}_{2}-$ fixing bacteria were selected by performing a nifH PCR assay (Ueda et al., 1995; Valdes et al., 2005), followed by an acetylene reduction experiment (Burris, 1972) using Winogradsky's $\mathrm{N}_{2}$-free mineral soft gel medium containing $1 \%$ mannitol (Hashidoko et al., 2002). Isolates SA41 ${ }^{\mathrm{T}}$, SA42 and SA53 from a plant of E. dulcis showed strong acetylene reduction activity. The three isolates formed round, smooth, convex, pale yellow colonies with entire margins on 1/10 TS ( $\mathrm{pH} 4.0$ ) plates. They showed good growth on these plates between 17 and $37{ }^{\circ} \mathrm{C}$ with an optimum at $32{ }^{\circ} \mathrm{C}$, but did not grow at 5 or $40{ }^{\circ} \mathrm{C}$. All three showed good growth over the $\mathrm{pH}$ range 3.5-9 with an optimum at 5, but no or little growth below $\mathrm{pH} 3$ or above 10 when cultured at $30{ }^{\circ} \mathrm{C}$ for 5 days. The isolates showed as good growth on TS ( $\mathrm{pH} 4.0$ ) plates as on 1/10 TS ( $\mathrm{pH}$ 4.0) plates. Growth under anaerobic conditions was determined after 5 days incubation at $30{ }^{\circ} \mathrm{C}$ in an AnaeroPack (Mitsubishi Gas Chemical Co.). The isolates showed good growth on 1/10 TS plates $(\mathrm{pH} 4.0)$ under aerobic conditions but not under anaerobic ones, thus suggesting them to be aerobic. The cells grown on 1/10 TS agar plates ( $\mathrm{pH} 4.0$ ) were Gram-negative (Ryu, 1938), nonendospore-forming and non-motile. Morphology was observed by scanning electron microscopy as described by Bogan et al. (2003) with slight modifications, including a replacement of gold by platinum-palladium for sputtercoating. The observed cells were irregular rods, $0.6-0.7 \mu \mathrm{m}$ wide and $1.5-1.7 \mu \mathrm{m}$ long, when the organisms were cultured on $1 / 10$ TS agar plates $(\mathrm{pH} 4.0)$ at $28{ }^{\circ} \mathrm{C}$ for 3 days (Supplementary Fig. S1 available in IJSEM Online).

The 16S rRNA genes of the isolates were amplified by PCR using universal primers (Tamura \& Hatano, 2001), and nearly complete $16 \mathrm{~S}$ rRNA gene nucleotide sequences were determined. The sequences showed high similarities to those of species within the genus Burkholderia. The 16S rRNA gene sequence similarities of strain $\mathrm{SA} 41^{\mathrm{T}}$ (AB495123) to strains SA42 (AB495124) and SA53 (AB495125), and to Burkholderia silvatlantica (AY965240), Burkholderia mimosarum (AY752958), Burkholderia ferrariae (DQ514537) and Burkholderia tropica (AJ420332) were 99.9, 99.8, 98.5, 98.2, 98.0 and $97.0 \%$, respectively. The phylogenetic relationship with closely related species was determined by using MEGA version 4 (Tamura et al., 2007) and the PHYLIP 3.65 package
(Felsenstein, 2005) after multiple alignments of the data performed with CLUSTAL_X (Thompson et al., 1997). Evolutionary distances were computed as described by Jukes \& Cantor (1969). Phylogenetic trees were constructed by using the maximum-parsimony (Kluge \& Farris, 1969), maximum-likelihood (Felsenstein, 1981) and neighbourjoining (Saitou \& Nei, 1987) methods. The reliabilities of these tree topologies were evaluated by bootstrap analysis with 1000 replicates (Felsenstein, 1985). The phylogenetic trees constructed by these three methods were topologically similar and showed that isolates SA $41^{\mathrm{T}}$, SA42 and SA53 belonged to the genus Burkholderia. The phylogenetic tree constructed by using the neighbour-joining method is shown in Fig. 1. Although the isolates showed a high degree of $16 \mathrm{~S}$ rRNA gene sequence similarity to established species of Burkholderia, they formed a separate line of descent in the phylogenetic cluster of the genus (Fig. 1 and Supplementary Fig. S2 available in IJSEM Online). Stackebrandt \& Goebel (1994) pointed out that a high degree of $16 \mathrm{~S}$ rRNA gene sequence similarity ( $97 \%$ or higher) is of limited value for differentiating species and that DNA-DNA hybridization studies must be performed to determine species affiliation under these circumstances. Therefore, we performed DNADNA hybridization on these isolates and their neighbours on the phylogenetic tree by using the microplate hybridization method (Ezaki et al., 1988, 1989; Tamura et al., 1999). The DNA-DNA relatedness values of isolates $\mathrm{SA} 41^{\mathrm{T}}$ with SA42 and SA53 were 94 and $89 \%$, respectively, which were higher than the recommended threshold value for the delineation of genomic species (70\%; Wayne et al., 1987) and also indicated that these three isolates represent three separate strains. Strain $S A 41^{\mathrm{T}}$ exhibited relatively low levels of DNADNA relatedness with respect to Burkholderia silvatlantica (39\%), Burkholderia mimosarum (41\%), Burkholderia ferrariae (39\%) and Burkholderia tropica (33\%), indicating that strain $S A 41^{\mathrm{T}}$ was not related to them at the species level. These data suggest that strains SA41 ${ }^{\mathrm{T}}, \mathrm{SA} 42$ and SA53 represent a novel species of the genus Burkholderia.

Additionally, strains SA41 ${ }^{\mathrm{T}}$, SA42 and SA53 could be distinguished from closely related species of Burkholderia on the basis of physiological characteristics (Table 1). These three strains were also phenotypically distinguishable from each other by acid production from melibiose, utilization of D-serine and resistance to gentamicin, oxolinic acid and enrofloxacin (Supplementary Table S1 available in IJSEM Online). Standard physiological tests were carried out according to the methods described by Smibert \& Krieg (1994). Acid production from carbon sources, enzyme activities and resistance to antibiotics were assessed by using the API $50 \mathrm{CH}$ system, API ZYM and API 20 E systems, and the ATB VET system (bioMérieux), respectively, according to the manufacturer's instructions. The utilization of various substrates as sole carbon sources was tested by using Biolog GN2 Microplates (Biolog Identification System) in accordance with the manufacturer's instructions. Analyses of DNA G + C content and cellular fatty acids were performed as described by Tamura 


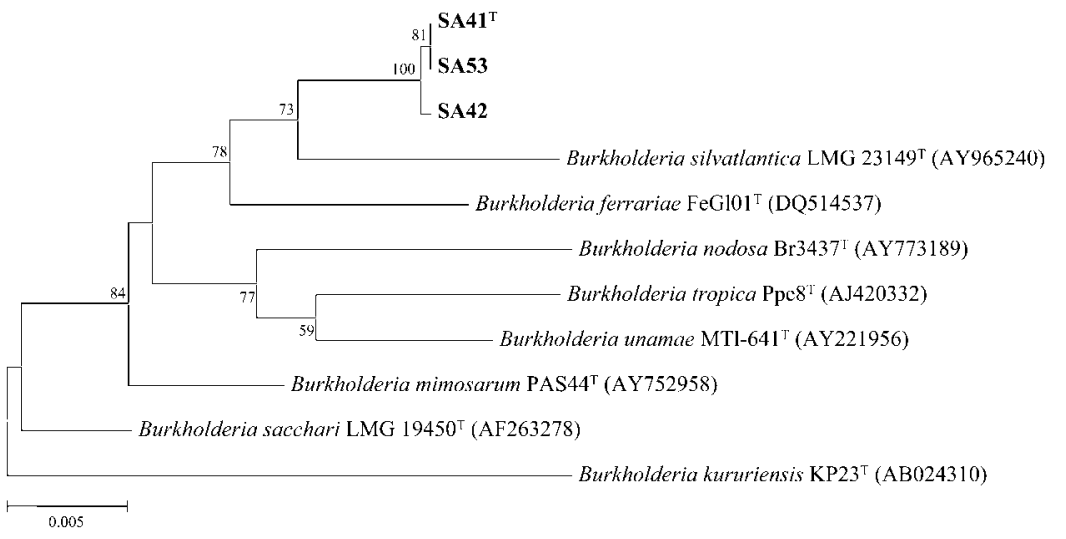

Fig. 1. Neighbour-joining tree based on nearly complete 16S rRNA gene sequences (positions 58-1440 of the Escherichia coli 16S rRNA gene), showing the positions of strains SA $41^{\top}$, SA42 and SA53 among closely related species of the genus Burkholderia. Numbers at branch nodes are values based on 1000 resamplings; only values over $50 \%$ are given. The sequence of Burkholderia kururiensis $\mathrm{KP}_{2} 3^{\top}$ was used as an outgroup. Bar, 0.005 nucleotide substitutions per nucleotide position.

et al. (1994). The major isoprenoid quinone was prepared as described previously (Tamura et al., 1994) and analysed by using a Quattro premier mass spectrometer coupled to an ACUITY UPLC (UPLC/MS/MS, Waters; Aizawa et al., 2010). The DNA G $+C$ content of strains $S A 41^{\mathrm{T}}$, SA42 and SA53 was $64 \mathrm{~mol} \%$. Major fatty acids of all three strains grown on $1 / 10$ TS agar plates containing $1 \%$ glucose (pH 5.0) at $28{ }^{\circ} \mathrm{C}$ for 3 days were $\mathrm{C}_{16: 0}, \mathrm{C}_{17: 0}$ cyclo, $\mathrm{C}_{18: 1}$ $\omega 7 c$ and summed feature $3\left(\mathrm{C}_{16: 1} \omega 7 c\right.$ and/or iso- $\mathrm{C}_{15: 0}$ 2-OH; Supplementary Table S2 available in IJSEM Online), and similar patterns were obtained from cells of the type strains of the closely related species in the genus. The major isoprenoid quinone of all three strains was determined to be Q-8, as in the case for other species of the genus Burkholderia (Yamada et al., 1982; Zhang et al., 2000; Yang et al., 2006; Valverde et al., 2006).

Whole-cell protein extracts were prepared from the three strains and the type strains of several related species, and analysed by SDS-PAGE as described by Pot et al. (1994); the results are shown in Supplementary Fig. S3 in IJSEM Online. The three newly isolated strains showed almost identical protein profiles among themselves (lanes 1-3), but their protein patterns were clearly different from those of other related species of Burkholderia (lanes 4-10). Since it is a well-known fact that bacteria with identical or very similar protein patterns possess high levels of genome similarity (Vandamme et al., 1996), the SDSPAGE results also support the notion that strains $S A 41^{\mathrm{T}}$, SA42 and SA53 represent a novel $\mathrm{N}_{2}$-fixing Burkholderia species.

Therefore, based on the physiological, biochemical, chemotaxonomic and molecular genetic results described above, strains SA41 ${ }^{\mathrm{T}}, \mathrm{SA} 42$ and SA53 represent a novel species of the genus Burkholderia, for which the name Burkholderia heleia sp. nov. is proposed.

\section{Description of Burkholderia heleia sp. nov.}

Burkholderia heleia (he.le'ia. Gr. n. heleios a marsh, low ground, meadow; N.L. fem. adj. heleia of the marsh, referring to the isolation of this species from a plant growing in a marsh).
The cells are Gram-negative, strictly aerobic, non-sporeforming, non-motile rods $(0.6-0.7 \mu \mathrm{m} \times 1.5-1.7 \mu \mathrm{m})$. Colonies are smooth, round, convex and pale yellow with entire margins after cultivation for 3 days at $32{ }^{\circ} \mathrm{C}$ on $1 / 10$ tryptic soy agar plates ( $\mathrm{pH} 4.0)$. Growth occurs between 17 and $42{ }^{\circ} \mathrm{C}$ with an optimum at $32{ }^{\circ} \mathrm{C}$. The $\mathrm{pH}$ range for growth is 3.5-9.0, with optimum growth at $\mathrm{pH}$ 5.0. The bacteria grow on MacConkey agar at $29{ }^{\circ} \mathrm{C}$, but not at $37^{\circ} \mathrm{C}$. Growth and acetylene reduction to ethylene occur on $\mathrm{N}_{2}$-free soft gel medium. Tweens 20,40 and 60 are hydrolysed, but Tween 80 is not. Positive for esterase (C4), esterase lipase (C8), $\beta$-glucosidase and urease activities, but negative for valine arylamidase, cystine arylamidase and arginine dihydrolase activities (API ZYM, API 20E and API 20NE systems). Positive for acid production from erythritol, D-xylose, D-adonitol, L-sorbose, dulcitol, aesculin, salicin, D-lactose, trehalose, xylitol and gentiobiose, but negative for acid production from D-mannose, L-rhamnose, arbutin, maltose, sucrose, raffinose, L-arabitol, potassium gluconate, potassium 2-ketogluconate and potassium 5-ketogluconate (API 50CH system). Can utilize adonitol, cellobiose, $i$-erythritol, L-rhamnose, trehalose, quinic acid, L-ornithine, 2-aminoethanol and D-glucose 6phosphate as sole carbon source, but not $N$-acetyl-Dgalactosamine, gentiobiose, $\alpha$-D-lactose, lactulose, maltose, melibiose, raffinose, sucrose, turanose, xylitol, D-galacturonic acid, D-glucuronic acid, $\gamma$-hydroxybutyric acid, itaconic acid, $\alpha$-ketovaleric acid, malonic acid, D-saccharic acid, glucuronamide, glycyl-L-aspartic acid, DL-carnitine, inosine, phenylethylamine, 2,3-butanediol or $\alpha$-D-glucose 1-phosphate (Biolog GN2 Microplate system). Resistant to streptomycin $\left(8 \mu \mathrm{g} \mathrm{ml} \mathrm{m}^{-1}\right)$, chloramphenicol $(8 \mu \mathrm{g}$ $\left.\mathrm{ml}^{-1}\right)$, erythromycin $\left(1 \mu \mathrm{g} \mathrm{ml} l^{-1}\right)$, tylosin $\left(2 \mu \mathrm{g} \mathrm{ml}^{-1}\right)$, colistin $\left(4 \mu \mathrm{g} \mathrm{ml}^{-1}\right)$, flumequin $\left(4 \mu \mathrm{g} \mathrm{ml}^{-1}\right)$ and rifampicin $\left(4 \mu \mathrm{g} \mathrm{ml}^{-1}\right)$, but sensitive to kanamycin $\left(8 \mu \mathrm{g} \mathrm{ml}^{-1}\right)$, apramycin $\left(16 \mu \mathrm{g} \mathrm{ml}^{-1}\right)$ and cotrimoxazole $(2 \mu \mathrm{g}$ trimethoprim ml ${ }^{-1}$ plus $38 \mu \mathrm{g} \mathrm{ml}^{-1}$ sulfamethoxazole) (API VET system). Additional physiological characteristics are summarized in Table 1. The major isoprenoid quinone is $\mathrm{Q}-8$, as described for the genus. The predominant cellular fatty acids are $\mathrm{C}_{16: 0}, \mathrm{C}_{17: 0}$ cyclo, $\mathrm{C}_{18: 1} \omega 7 c$ and summed feature $3\left(\mathrm{C}_{16: 1} \omega 7 c\right.$ and/or iso- $\left.\mathrm{C}_{15: 0} 2-\mathrm{OH}\right)$. The DNA $\mathrm{G}+\mathrm{C}$ content of these strains is $64 \mathrm{~mol} \%$. 
Table 1. Physiological characteristics of Burkholderia heleia sp. nov. and closely related type strains of Burkholderia species

Strains: 1, Burkholderia heleia sp. nov. SA $41^{\mathrm{T}}$, SA42 and SA53; 2, Burkholderia silvatlantica LMG $23149^{\mathrm{T}}$; 3, Burkholderia ferrariae LMG $23612^{\mathrm{T}}$; 4, Burkholderia nodosa LMG $23741^{\mathrm{T}} ; 5$, Burkholderia tropica LMG $22274^{\mathrm{T}}$; 6, Burkholderia unamae CIP $107921^{\mathrm{T}}$; 7, Burkholderia sacchari $\mathrm{LMG} 19450^{\mathrm{T}} ; 8$, Burkholderia mimosarum $\mathrm{LMG} 23256^{\mathrm{T}}$. +, Positive; -, negative; (+), weakly positive. All strains had the following characteristics: positive for hydrolysis of Tweens 20, 40 and 60; positive for oxidase, catalase; positive for acid and alkaline phosphatase, leucine arylamidase, naphthol-AS-BI-phosphohydrolase and nitrate reduction (API ZYM and API 20NE systems); negative for Gram stain and growth on MacConkey agar at $37{ }^{\circ} \mathrm{C}$; negative for hydrolysis of DNA and gelatin; negative for lipase (C4), trypsin, $\alpha$ chymotrypsin, $\alpha$-galactosidase, $\beta$-glucuronidase, $\alpha$-glucosidase, $N$ acetyl-D-glucosaminidase, $\alpha$-mannosidase, $\alpha$-fucosidase, proteinase, indole production and nitrate reduction to $\mathrm{N}_{2}$ (API ZYM and API 20NE systems); positive for acid production from glycerol, D- and Larabinose, D-ribose, D-xylose, D-galactose, D-glucose, D-fructose, inositol, D-mannitol, D-sorbitol, $N$-acetylglucosamine, cellobiose, Dlyxose, $\mathrm{D}$ - and L-fucose and D-arabitol (API 50CH system); negative for acid production from methyl- $\beta$-D-xylopyranoside, methyl- $\alpha$-D-mannopyranoside, methyl- $\alpha$-D-glucopyranoside, amygdalin, inulin, melezitose, starch, glycogen and turanose (API 50CH system); positive for utilization of Tweens 40 and 80, $\mathrm{N}$-acetyl-D-glucosamine, L-arabinose, D-arabitol, D-fructose, L-fucose, D-galactose, $\alpha$-D-glucose, $m$-inositol, D-mannitol, D-mannose, D-sorbitol, pyruvic acid methylester, succinic acid monomethylester, acetic acid, cis-aconitic acid, citric acid, formic acid, D-galactonic acid lactone, D-gluconic acid, D-glucosaminic acid, $\beta$-hydroxybutyric acid, $p$-hydroxyphenylacetic acid, $\alpha$-ketobutyric acid, $\alpha$-ketoglutaric acid, DL-lactic acid, propionic acid, sebacic acid, succinic acid, bromosuccinic acid, succinamic acid, L-alaninamide, D- and $\mathrm{L}$ alanine, L-alanylglycine, L-asparagine, L-aspartic acid, L-glutamic acid, glycyl-L-glutamic acid, L-histidine, hydroxy-L-proline, L-leucine, Lphenylalanine, L-proline, L-pyroglutamic acid, L-serine, L-threonine, $\gamma$ aminobutyric acid, urocanic acid and glycerol (Biolog GN2 Microplate system); negative for utilization of $\alpha$-cyclodextrin, $\beta$-methyl-Dglucoside, uridine and thymidine (Biolog GN2 Microplate system); resistant to penicillin $\left(0.25 \mu \mathrm{g} \mathrm{ml}^{-1}\right)$, amoxicillin $\left(4 \mu \mathrm{g} \mathrm{ml}^{-1}\right)$, amoxicillin $\left(4 \mu \mathrm{g} \mathrm{ml}^{-1}\right)$ plus clavulanic acid $\left(2 \mu \mathrm{g} \mathrm{ml}^{-1}\right)$, oxacillin $\left(2 \mu \mathrm{g} \mathrm{ml}^{-1}\right)$, cephalothin $\left(8 \mu \mathrm{g} \mathrm{ml}^{-1}\right)$, cefoperazone $\left(4 \mu \mathrm{g} \mathrm{ml}^{-1}\right)$, lincomycin $\left(2 \mu \mathrm{g} \mathrm{ml}^{-1}\right)$, pristinamycin $\left(2 \mu \mathrm{g} \mathrm{ml}^{-1}\right)$, sulfamethizole $\left(100 \mu \mathrm{g} \mathrm{ml}^{-1}\right)$, nitrofurantoin $\left(25 \mu \mathrm{g} \mathrm{ml}^{-1}\right)$, fusidic acid $\left(2 \mu \mathrm{g} \mathrm{ml}^{-1}\right)$ and metronidazole $\left(4 \mu \mathrm{g} \mathrm{ml}^{-1}\right)$ (API VET system); sensitive to spectinomycin $\left(64 \mu \mathrm{g} \mathrm{ml}^{-1}\right)$, tetracycline $\left(4 \mu \mathrm{g} \mathrm{ml}^{-1}\right)$ and doxycycline $\left(4 \mu \mathrm{g} \mathrm{ml}^{-1}\right.$ ) (API VET system).

\begin{tabular}{|c|c|c|c|c|c|c|c|c|}
\hline Characteristic & 1 & 2 & 3 & 4 & 5 & 6 & 7 & 8 \\
\hline \multicolumn{9}{|l|}{ Growth on: } \\
\hline $\begin{array}{l}\text { MacConkey agar at } \\
29{ }^{\circ} \mathrm{C}\end{array}$ & + & - & - & - & + & + & - & - \\
\hline \multicolumn{9}{|l|}{ Hydrolysis of: } \\
\hline Tween 80 & - & + & + & + & + & + & + & + \\
\hline \multicolumn{9}{|l|}{ Enzyme activity ${ }^{\star}$} \\
\hline Esterase (C4) & + & + & + & + & - & + & + & + \\
\hline Esterase lipase (C8) & + & + & + & + & - & + & + & + \\
\hline
\end{tabular}

Table 1. cont.

\begin{tabular}{|c|c|c|c|c|c|c|c|c|}
\hline Characteristic & 1 & 2 & 3 & 4 & 5 & 6 & 7 & 8 \\
\hline Valine arylamidase & - & + & + & - & - & - & + & - \\
\hline Cystine arylamidase & - & $(+)$ & + & - & - & - & + & - \\
\hline$\beta$-Galactosidase & - & - & - & + & - & - & - & - \\
\hline$\beta$-Glucosidase & + & + & - & - & - & - & - & - \\
\hline Arginine dihydrolase & - & + & + & + & - & - & $(+)$ & - \\
\hline Urease & + & + & + & + & - & - & - & + \\
\hline \multicolumn{9}{|c|}{ Acid production from: $\dagger$} \\
\hline Erythritol & + & + & - & $(+)$ & - & $(+)$ & - & - \\
\hline L-Xylose & + & - & $(+)$ & + & $(+)$ & + & - & - \\
\hline D-Adonitol & + & + & + & + & + & + & + & - \\
\hline D-Mannose & - & + & + & + & + & + & + & + \\
\hline L-Sorbose & + & - & - & - & $(+)$ & $(+)$ & - & - \\
\hline L-Rhamnose & - & + & + & + & + & + & - & - \\
\hline Dulcitol & + & - & + & - & - & - & - & - \\
\hline Arbutin & - & - & - & $(+)$ & - & $(+)$ & - & $(+)$ \\
\hline Aesculin & + & - & $(+)$ & $(+)$ & $(+)$ & $(+)$ & - & $(+)$ \\
\hline Salicin & + & $(+)$ & $(+)$ & $(+)$ & + & $(+)$ & - & $(+)$ \\
\hline Maltose & - & - & + & - & - & + & - & - \\
\hline D-Lactose & + & - & + & - & $(+)$ & + & - & + \\
\hline Melibiose & $\mathrm{v}$ & - & - & - & + & + & - & - \\
\hline Sucrose & - & + & - & - & - & - & + & - \\
\hline Trehalose & + & - & + & + & + & + & - & - \\
\hline Raffinose & - & + & - & - & - & - & + & - \\
\hline Xylitol & + & - & - & + & $(+)$ & - & - & - \\
\hline Gentiobiose & + & + & $(+)$ & $(+)$ & + & + & - & - \\
\hline D-Tagatose & $(+)$ & - & + & - & - & $(+)$ & - & - \\
\hline L-Arabitol & - & - & - & - & - & $(+)$ & $(+)$ & - \\
\hline Potassium gluconate & - & $(+)$ & - & - & - & $(+)$ & - & - \\
\hline $\begin{array}{l}\text { Potassium } \\
\text { 2-ketogluconate }\end{array}$ & - & $(+)$ & - & - & - & $(+)$ & $(+)$ & - \\
\hline $\begin{array}{l}\text { Potassium } \\
\text { 5-ketogluconate }\end{array}$ & - & - & - & - & - & - & $(+)$ & - \\
\hline \multicolumn{9}{|l|}{ Utilization of: $\ddagger$} \\
\hline Dextrin & $(+)$ & - & $(+)$ & - & $(+)$ & - & - & + \\
\hline Glycogen & $(+)$ & $(+)$ & $(+)$ & + & $(+)$ & - & $(+)$ & + \\
\hline $\begin{array}{l}N \text {-Acetyl-D- } \\
\text { galactosamine }\end{array}$ & - & + & + & - & - & $(+)$ & $(+)$ & - \\
\hline Adonitol & + & + & + & + & + & + & + & - \\
\hline Cellobiose & + & + & + & + & $(+)$ & + & - & - \\
\hline$i$-Erythritol & + & + & - & + & - & + & + & + \\
\hline Gentiobiose & - & + & + & - & $(+)$ & - & - & - \\
\hline$\alpha$-D-Lactose & - & - & $(+)$ & - & - & - & - & - \\
\hline Lactulose & - & - & + & - & + & - & + & + \\
\hline Maltose & - & - & $(+)$ & - & - & $(+)$ & - & - \\
\hline Melibiose & - & - & - & - & $(+)$ & - & - & - \\
\hline D-Psicose & $(+)$ & - & $(+)$ & + & + & $(+)$ & $(+)$ & $(+)$ \\
\hline Raffinose & - & + & - & - & - & - & + & - \\
\hline L-Rhamnose & + & + & + & + & + & + & + & - \\
\hline Sucrose & - & + & - & - & - & $(+)$ & + & - \\
\hline Trehalose & + & - & + & + & + & + & - & - \\
\hline Turanose & - & - & - & - & - & $(+)$ & - & - \\
\hline Xylitol & - & - & $(+)$ & + & - & - & - & - \\
\hline D-Galacturonic acid & - & - & + & + & + & + & - & + \\
\hline
\end{tabular}


Table 1. cont.

\begin{tabular}{|c|c|c|c|c|c|c|c|c|}
\hline Characteristic & 1 & 2 & 3 & 4 & 5 & 6 & 7 & 8 \\
\hline D-Glucuronic acid & - & - & + & - & - & $(+)$ & - & - \\
\hline$\alpha$-Hydroxybutyric acid & $(+)$ & + & + & - & + & $(+)$ & + & + \\
\hline$\gamma$-Hydroxybutyric acid & - & - & + & + & - & + & $(+)$ & + \\
\hline Itaconic acid & - & + & - & + & $(+)$ & + & + & + \\
\hline$\alpha$-Ketovaleric acid & - & $(+)$ & + & - & $(+)$ & $(+)$ & + & + \\
\hline Malonic acid & - & + & - & - & - & $(+)$ & $(+)$ & + \\
\hline Quinic acid & + & - & + & + & + & + & + & + \\
\hline D-Saccharic acid & - & $(+)$ & + & + & + & + & + & + \\
\hline Glucuronamide & - & + & + & - & + & $(+)$ & $(+)$ & - \\
\hline Glycyl-L-aspartic acid & - & + & + & + & - & - & + & + \\
\hline L-Ornithine & + & + & + & - & $(+)$ & $(+)$ & + & + \\
\hline DL-Carnitine & - & - & - & - & $(+)$ & - & + & - \\
\hline Inosine & - & - & - & - & $(+)$ & + & - & - \\
\hline Phenylethylamine & - & - & - & + & - & - & - & + \\
\hline Putrescine & $(+)$ & - & - & - & - & - & - & - \\
\hline 2-Aminoethanol & + & + & - & - & + & + & + & + \\
\hline 2,3-Butanediol & - & - & - & - & $(+)$ & $(+)$ & - & - \\
\hline DL- $\alpha$-Glycerol phosphate & $(+)$ & + & + & - & $(+)$ & $(+)$ & + & - \\
\hline $\begin{array}{l}\alpha \text {-D-Glucose } 1- \\
\text { phosphate }\end{array}$ & - & - & - & - & $(+)$ & $(+)$ & + & - \\
\hline D-Glucose 6-phosphate & + & + & + & + & + & + & + & - \\
\hline \multicolumn{9}{|l|}{$\begin{array}{l}\text { Resistance to }(\mu \mathrm{g} \\
\left.\mathrm{ml}^{-1}\right): \S\end{array}$} \\
\hline Streptomycin (8) & + & $(+)($ & $(+)$ & - & - & - & + & + \\
\hline Kanamycin (8) & - & $(+)$ & - & - & - & - & - & - \\
\hline Apramycin (16) & - & $(+)$ & - & - & - & - & $(+)$ & - \\
\hline Chloramphenicol (8) & + & + & + & + & - & - & + & + \\
\hline Erythromycin (1) & + & + & + & + & - & - & + & + \\
\hline Tylosin (2) & + & + & + & + & - & + & + & + \\
\hline Colistin (4) & + & + & + & + & - & - & + & + \\
\hline Cotrimoxazole $(2 / 38)$ & - & $(+)$ & + & + & - & - & + & + \\
\hline Flumequin (4) & + & + & + & - & - & - & + & - \\
\hline Rifampicin (4) & + & + & + & + & - & $(+)$ & + & + \\
\hline
\end{tabular}

${ }^{*}$ Results obtained by using the API ZYM and API 20 NE systems. $\uparrow$ Results obtained by using the API $50 \mathrm{CH}$ system.

$\ddagger$ Results obtained by using the Biolog GN2 Microplate system. $\S$ Results obtained by using the API VET system.

The type strain, SA41 ${ }^{\mathrm{T}}\left(=\right.$ NBRC $101817^{\mathrm{T}}=$ VTCC-D6- $\left.7^{\mathrm{T}}\right)$, was isolated from an aquatic plant, Eleocharis dulcis, that grows luxuriantly in a highly acidic swamp ( $\mathrm{pH} 3)$ in an AASS area in Vietnam.

\section{Acknowledgements}

We are most grateful to S. Sasaki for giving us the opportunity to conduct this research. We are grateful to $\mathrm{H}$. Uchiyama for identification of E. dulcis; to I. Hasegawa, H. Sumida, A. Noguchi, M. Kawahigasi, M. N. Do, H. Le and N. H. Ngo for help in collecting the samples; and M. Ohkuma and S. Noda for advice on the acetylene reduction assay. We acknowledge T. Morita, T. Asai, M. Shimizu, G. Hashimoto, K. Kimoto, T. Taguti and various members of our laboratories for their technical assistance and encouragement. We acknowledge D. V. Hop at the VTCC, K. Suzuki, Y. Nakagawa and Y.
Muramatsu at the NBRC for the deposit of the isolates, and M. Hyoudou, M. Kogure, N. Murayama and N. Sekino at the Integrated Research Institute for their technical assistance. This study was partly supported by a grant from the Institute for Fermentation (IFO; Osaka, Japan), and by grants-in-aid for scientific research (nos. 21780300 and 20580365) from the Japan Society for Promotion of Science. T. A. was supported by funding from the 'Center of Excellence in 21st Century Projects' and 'High-Tech Research Center Projects' of the Ministry of Education, Culture, Sports, Science and Technology of Japan.

\section{References}

Aizawa, T., Nguyen, B. V., Kimoto, K., Iwabuchi, N., Sumida, H., Hasegawa, I., Sasaki, S., Tamura, T., Kudo, T. \& other authors (2007). Curtobacterium ammoniigenes sp. nov., an ammonia-producing bacterium isolated from plants inhabiting acidic swamps in actual acid sulfate soil areas of Vietnam. Int J Syst Evol Microbiol 57, 1447-1452.

Aizawa, T., Urai, M., Iwabuchi, N., Nakajima, M. \& Sunairi, M. (2010). Bacillus trypoxylicola sp. nov., xylanase-producing alkaliphilic bacteria isolated from the guts of Japanese horned beetle larvae (Trypoxylus dichotomus septentrionalis). Int J Syst Evol Microbiol 60, 61-66.

Bogan, B. W., Sullivan, W. R., Kayser, K. J., Derr, K. D., Aldrich, H. C. \& Paterek, J. R. (2003). Alkanindiges illinoisensis gen. nov., sp. nov., an obligately hydrocarbonoclastic, aerobic squalane-degrading bacterium isolated from oilfield soils. Int J Syst Evol Microbiol 53, 1389-1395.

Burris, R. H. (1972). Nitrogen fixation assay methods and techniques. Methods Enzymol 24, 415-431.

Caballero-Mellado, J., Martı'nez-Aguilar, L., Paredes-Valdez, G. \& Estrada-de los Santos, P. (2004). Burkholderia unamae sp nov., an $\mathrm{N}_{2}$-fixing rhizospheric and endophytic species. Int J Syst Evol Microbiol 54, 1165-1172.

Chen, W. M., James, E. K., Coenye, T., Chou, J. H., Barrios, E., de Faria, S. M., Elliott, G. N., Sheu, S. Y., Sprent, J. I. \& Vandamme, P. (2006). Burkholderia mimosarum sp. nov., isolated from root nodules of Mimosa spp. from Taiwan and South America. Int J Syst Evol Microbiol 56, 1847-1851.

Chen, W.-M., de Faria, S. M., James, E. K., Elliott, G. N., Lin, K.-Y., Chou, J.-H., Sheu, S.-Y., Cnockaert, M., Sprent, J. I. \& Vandamme, P. (2007). Burkholderia nodosa sp. nov., isolated from root nodules of the woody Brazilian legumes Mimosa bimucronata and Mimosa scabrella. Int J Syst Evol Microbiol 57, 1055-1059.

Ezaki, T., Hashimoto, Y., Takeuchi, N., Yamamoto, H., Liu, S. L., Miura, H., Matsui, K. \& Yabuuchi, E. (1988). Simple genetic method to identify viridans group streptococci by colorimetric dot hybridization and fluorometric hybridization in microdilution wells. J Clin Microbiol 26, 1708-1713.

Ezaki, T., Hashimoto, Y. \& Yabuuchi, E. (1989). Fluorometric deoxyribonucleic acid-deoxyribonucleic acid hybridization in microdilution wells as an alternative to membrane filter hybridization in which radioisotopes are used to determine genetic relatedness among bacterial strains. Int J Syst Bacteriol 39, 224-229.

Felsenstein, J. (1981). Evolutionary trees from DNA sequences: a maximum likelihood approach. J Mol Evol 17, 368-376.

Felsenstein, J. (1985). Confidence limits on phylogenies: an approach using the bootstrap. Evolution 39, 783-791.

Felsenstein, J. (2005). PHYLIP (phylogeny inference package) version 3.65. Distributed by the author. Department of Genome Sciences, University of Washington, Seattle, USA.

Gillis, M., Van Van, T., Bardin, R., Goor, M., Hebbar, P., Willems, A., Segers, P., Kersters, K., Heulin, T. \& Fernandez, M. P. (1995). 
Polyphasic taxonomy in the genus Burkholderia leading to an emended description of the genus and proposition of Burkholderia vietnamiensis sp. nov. for $\mathrm{N}_{2}$-fixing isolates from rice in Vietnam. Int $\mathrm{J}$ Syst Bacteriol 45, 274-289.

Goris, J., De Vos, P., Caballero-Mellado, J., Park, J.-H., Falsen, E., Quensen, J. F., III, Tiedje, J. M. \& Vandamme, P. (2004). Classification of the PCB- and biphenyl-degrading strain LB400 and relatives as Burkholderia xenovorans sp. nov. Int J Syst Evol Microbiol 54, 16771681.

Hashidoko, Y., Tada, M., Osaki, M. \& Tahara, S. (2002). Soft gel medium solidified with gellan gum for preliminary screening for root-associating, free-living nitrogen-fixing bacteria inhabiting the rhizoplane of plants. Biosci Biotechnol Biochem 66, 2259-2263.

Jukes, T. H. \& Cantor, C. R. (1969). Evolution of protein molecules. In Mammalian Protein Metabolism, vol. 3, pp. 21-132. Edited by H. N. Munro. New York: Academic Press.

Kluge, A. G. \& Farris, J. S. (1969). Quantitative phyletics and the evolution of anurans. Syst Zool 18, 1-32.

Perin, L., Martinez-Aguilar, L., Paredes-Valdez, G., Baldani, J. I., Estrada-de los Santos, P., Reis, V. M. \& Caballero-Mellado, J. (2006). Burkholderia silvatlantica sp. nov., a diazotrophic bacterium associated with sugar cane and maize. Int J Syst Evol Microbiol 56, 1931-1937.

Pot, B., Vandamme, P. \& Kersters, K. (1994). Analysis of electrophoretic whole-organism protein fingerprints. In Chemical Methods in Prokaryotic Systematics, pp. 493-521. Edited by M. Goodfellow \& A. G. O'Donnell. Chichester: Wiley.

Reis, V. M., Estrada-de los Santos, P., Tenorio-Salgado, S., Vogel, J., Stoffels, M., Guyon, S., Mavingui, P., Baldani, V. L., Schmid, M. \& other authors (2004). Burkholderia tropica sp. nov., a novel nitrogenfixing, plant-associated bacterium. Int J Syst Evol Microbiol 54, 21552162.

Ryu, E. (1938). On the Gram-differentiation of bacteria by the simplest method. J Jpn Soc Vet Sci 17, 31.

Saitou, N. \& Nei, M. (1987). The neighbor-joining method: a new method for reconstructing phylogenetic trees. Mol Biol Evol 4, 406425.

Sasaki, S., Ishii, R., Hasegawa, I. \& other authors (2008). Development of New Bioremediation Systems of Acid Sulfate Soil for Agriculture and Forestry. Kyoto, Japan: Nakanishi Printing Co. Ltd.

Smibert, R. M. \& Krieg, N. R. (1994). Phenotypic characterization. In Methods for General and Molecular Bacteriology, pp. 607-654. Edited by P. Gerhardt, R. G. E. Murray, W. A. Wood \& N. R. Krieg. Washington, DC: American Society for Microbiology.

Stackebrandt, E. \& Goebel, B. M. (1994). Taxonomic note: a place for DNA-DNA reassociation and $16 \mathrm{~S}$ rRNA sequence analysis in the present species definition in bacteriology. Int J Syst Bacteriol 44, 846849.

Tamura, T. \& Hatano, K. (2001). Phylogenetic analysis of the genus Actinoplanes and transfer of Actinoplanes minutisporangius Ruan et al., 1986 and 'Actinoplanes aurantiacus' to Cryptosporangium minutispor- angium comb. nov. and Cryptosporangium aurantiacum sp. nov. Int $J$ Syst Evol Microbiol 51, 2119-2125.

Tamura, T., Nakagaito, Y., Nishii, T., Hasegawa, T., Stackebrandt, E. \& Yokota, A. (1994). A new genus of the order Actinomycetales, Couchioplanes gen. nov., with descriptions of Couchioplanes caeruleus (Horan and Brodsky, 1986) comb. nov. and Couchioplanes caeruleus subsp. azureus subsp. nov. Int J Syst Bacteriol 44, 193-203.

Tamura, T., Hayakawa, M. \& Hatano, K. (1999). Sporichthya brevicatena sp. nov. Int J Syst Bacteriol 49, 1779-1784.

Tamura, K., Dudley, J., Nei, M. \& Kumar, S. (2007). MEGA4: Molecular Evolutionary Genetics Analysis (MEGA) Software Version 4.0. Mol Biol Evol 24, 1596-1599.

Thompson, J. D., Gibson, T. J., Plewniak, F., Jeanmougin, F. \& Higgins, D. G. (1997). The CLUSTAL_X windows interface: flexible strategies for multiple sequence alignment aided by quality analysis tools. Nucleic Acids Res 25, 4876-4882.

Ueda, T., Suga, Y., Yahiro, N. \& Matsuguchi, T. (1995). Remarkable $\mathrm{N}_{2-}$ fixing bacterial diversity detected in rice roots by molecular evolutionary analysis of nifH gene sequences. J Bacteriol 177, 1414-1417.

Valdes, M., Perez, N.-O., Estrada-de los Santos, P., CaballeroMellado, J., Pena-Cabriales, J. J., Normand, P. \& Hirsch, A. M. (2005). Non-Frankia Actinomycetes isolated from surface-sterilized roots of Casuarina equisetifolia fix nitrogen. Appl Environ Microbiol 71, 460466.

Valverde, A., Delvasto, P., Peix, A., Velázquez, E., Santa-Regina, I., Ballester, A., Rodríguez-Barrueco, C., Garcia-Balboa, C. \& Igual, J. M. (2006). Burkholderia ferrariae sp. nov., isolated from an iron ore in Brazil. Int J Syst Evol Microbiol 56, 2421-2425.

Vandamme, P., Pot, B., Gillis, M., de Vos, P., Kersters, K. \& Swings, J. (1996). Polyphasic taxonomy, a consensus approach to bacterial systematics. Microbiol Rev 60, 407-438.

Wayne, L. G., Brenner, D. J., Colwell, R. R., Grimont, P. A. D., Kandler, O., Krichevsky, M. I., Moore, L. H., Moore, W. E. C., Murray, R. G. E. \& other authors (1987). International Committee on Systematic Bacteriology. Report of the ad hoc committee on reconciliation of approaches to bacterial systematics. Int J Syst Bacteriol 37, 463-464.

Yabuuchi, E., Kosako, Y., Oyaizu, H., Yano, I., Hotta, H., Hashimoto, Y., Ezaki, T. \& Arakawa, M. (1992). Proposal of Burkholderia gen. nov. and transfer of seven species of the genus Pseudomonas homology group II to the new genus, with the type species Burkholderia cepacia (Palleroni and Holmes 1981) comb. nov. Microbiol Immunol 36, 12511275 .

Yamada, Y., Takinami-Nakamura, H., Tahara, Y., Oyaizu, H. \& Komagata, K. (1982). The ubiquinone systems in the strains of Pseudomonas species. J Gen Appl Microbiol 28, 7-12.

Yang, H. C., Im, W. T., Kim, K. K., An, D. S. \& Lee, S. T. (2006). Burkholderia terrae sp. nov., isolated from a forest soil. Int J Syst Evol Microbiol 56, 453-457.

Zhang, H., Hanada, S., Shigematsu, T., Shibuya, K., Kamagata, Y., Kanagawa, T. \& Kurane, R. (2000). Burkholderia kururiensis sp. nov., a trichloroethylene (TCE)-degrading bacterium isolated from an aquifer polluted with TCE. Int J Syst Evol Microbiol 50, 743-749. 